- FINANSE I PRAWO FINANSOWE

- Journal of Finance and Financial Law

Wrzesień/September 2020 • vol. 3(27): 7-24

http://dx.doi.org/10.18778/2391-6478.3.27.01

\title{
GROWTH OF COMPANIES AND GROWTH POTENTIAL ON THE EXAMPLE OF BUSINESS SERVICES FOR FIRMS SECTOR ON NEWCONNECT MARKET
}

\author{
Monika Bolek \\ Wydział Ekonomiczno-Socjologiczny, Uniwersytet Łódzki \\ ORCID: https://orcid.org/0000-0001-9376-1105
}

Bartosz Czulak

\begin{abstract}
The article is related to the growth of young companies operating in the business services for firms sector, that are listed on the Warsaw Stock Exchange alternative market - NewConnect. The growth opportunity models are introduced to explain the growth process of these companies together with other controlling factors such as profitability, size of the company and its earnings. As the result of the research it is found that growth potential is negatively correlated with assets and equity growth in short term, but it affects positively earnings per share growth in a longer, three-year period. It can therefore be concluded that in the sector taken into consideration, investors' decisions reflected in the growth potential measures may be translated into company's value growth only in a longer term.
\end{abstract}

Keywords: growth, growth potential, business services sector.

JEL Class: G10, M20. 


\section{INTRODUCTION}

The growth of company is desired by current owners as well as potential investors, who are guided by growth opportunity in decision-making process of buying shares or selling them. Growth is multi-dimensional issue connected with, among others, assets, equity, sales and earnings per share. Earnings per share growth reflects the company's value growth, therefore this ratio plays an important role in the companies' growth assessment on capital market.

Numbers of factors determine company's growth, they have both external character arising from micro- and macro conditions, as well as internal, related to the company in itself. Therefore, the identification of the determinants is extremely significant because it provides crucial information for the company's managers and investors. One of the factors influencing company's growth is growth potential, which expresses market's expectations in relation to company's value in the future. These expectations influence shares' price, related to the present value of future investment projects.

There are not many papers related to the growth and growth potential analysis of companies operating on capital market. The most known are those presented by Danbolt, Hirst and Jones [2011] and Kallapur and Trombley [1999] who performed the research on the UK and USA markets respectively. Their findings indicate that the growth of earnings per share forecast is not possible with the growth opportunity measures, although the theoretical models should explain this relationship. In this paper similar approach is applied for the research sample of companies traded on the Polish alternative exchange in the business services for firms sector.

The goal of this paper is related to the presentation of the companies' growth issue, its measurement and determinants. In the following article the thesis: the growth of selected companies is related to their growth potential is verified. Correlations of the companies' growth and selected growth potential measures are subject of analysis together with the regression models.

The sector that has been chosen for the research is one of the largest branches of NewConnect, when market value is taken into consideration. NewConnect as an exchange was created to support the growth of young and small companies by offering the access to the capital. Most of the companies within the business services for firms sector are small and young enterprises, practicing consultancy in different forms, but the most common activities are accounting, tax and broadly understood business consultancy services. There are global companies operating in this sector, namely Big Four: Deloitte, PWC, EY, KPMG and they origins are related to the young company stage, therefore it is possible, that one of the companies traded on NewConnect exchange will be able to grow and develop toward the global company.

The paper consists of several sections: literature analysis, the description of data, methodology, results and conclusions. 


\section{THE ANALYSIS OF THE LITERATURE}

The company's growth belongs to one of the more complex aspects of economics, due to diversity of business profiles. The growth measurement and factors determining this process are the subject of academics' studies seeking to formulate uniform theory in this area, which still needs to be developed. It can be concluded that the choice of growth measure determines the results of research. The most often used measures are the employment or production volume [Kurczewska 2008], financial measures are related to the growth of assets, equity, sales or earnings per share [Bolek 2018]. One of the reasons for using sales as the growth factor is the simplicity of data acquisition, as well as the relevance of this measure in the assessment of short-term and long-term changes occurring in the company [Ardishvili et al., 1998].

The concept of the organization's growth is often treated interchangeably with development, but they are not synonyms. Generally, development is a continued process of targeted changes, in which consecutive phases of transformation can be distinguished. Between the growth and development there is a fundamental difference. The aspect of the enterprise's development is usually wider than growth. The growth is meant to be a positive, measureable change in the company's size. Growth usually occurs as a result of changes in existing system of enterprise's value, while development is achieved by multiple internal adjustments, which result in the increase in organization's size and are reflected in its characteristics. Development leads to shaping a hierarchy of enterprise's goals, in scope of internal relations, as well as in the area of company's relationship with the environment [Czarnecki 2011].

Piasecki presented the idea of the growth theory of small- and mid-sized enterprises by describing theoretical concepts of small company and by analyzing an effective scale of enterprise's size [Piasecki 1997, 1998]. Relatively, much has been written about company's growth in respect of larger organizations [Gajęcki 1997; Machaczka 1998; Gruszecki 2002] and enterprise's strategies of growth [Pierścionek 1997; Obłój 2002]. The group of researchers studying the concepts of growth of small- and mid-sized enterprises is in fact limited, i.e. Delmar, Wiklund, Davidsson are mentioned the most often [Wasilczuk 2005].

Changes taking place in the environment and activities of the enterprise require a new approach for managing growth process, but first of all the financial perspective should be taken into consideration. Modern companies should identify the possibilities inherent in branch and in the market, but first of all they should be able to assess the consequences of their own actions within the context of competitors and the future conditions, so the strategy would create the value. Managing the growth process should contribute to a creation of the value. The management, from the other hand, is determined by business strategy, which 
can be estimated based on the quantities implied by a sustainable growth model as a reference point. The decisions regarding enterprise's growth and development should create the value [Pomykalska 2010]. Gancarczyk i Gancarczyk [2011] concluded from the other hand, that the company's growth is related to the internationalization processes that is a strategic decision, too.

The proposals for the enterprises' growth models are one of the most important aspects of the growth theory because of different possibilities of the perception of company (economical, marketing, behavioral, organizational and financial). Basing on this statement, Sysko-Romańczuk [2005] analyzed essence, models, processes of modeling and measuring the company's growth. So far, researchers were unable to formulate an unified scheme of company's growth, and also they couldn't define all factors determining it, also in the area of finances, due to the fact that growth is a very complex and complicated process

The growth process is not linear and moreover it is related to the stages of growth. In the McGuiere's model [1963], there were distinguished five phases of company's growth. McGuiere's model was created in the times, when the economic reality in capitalistic countries was less complex and growth was described in a linear way. In the model presented by Christiansen and Scott [1964], the authors focused on a comprehensive description of organization's development in association both with the market, and offered products. They identified and described three phases of enterprise's growth in areas connected with its size, the amount of offered products and the share of the market. Steinmetz's model [1969] is based on five stages of growth, ending with critical situations, which may allow the company to move on to the next phase of development. The most known enterprise's growth model, which represents evolutionary perspective, is the Greiner's life cycle model [1972]. The organization's development is the result of evolutionary periods, interrupted by the events of revolutionary character. The standard theory of organization's life cycle implies that it develops in several stages. Greiner pulled off five main factors determining the organization's development: age, size, and phase of evolution, stage of revolution and rate of branch's growth. The next model presented by Lewis and Churchill [1987], related to the gradual growth was adopted from the biology science and development of living organisms on the assumption that enterprise goes through the same development stages. They presented five phases of company's development: the creation, survival, success, rapid growth and maturity. Scott and Bruce [1987] suggested a model, in which they distinguished five phases of small enterprises' growth. In company's life cycle model Hanks et al. [1993] defined the growth as a configuration of several variables connected with business activity: size, age, growth rate and targets for action in conjunction with organization's structure. Within the context of these variables the enterprise goes through life cycles called by the authors: startup, 
expansion, maturity and diversification. The growth in itself is therefore related to the process assessment with stages of growth that are influenced by external and internal factors.

Lotti et al. [2003] conducted a research among small enterprises and found that startups need to grow rapidly to reach a size that allows them to survive, and therefore, in the initial period of their development, the law of proportional growth does not work. In the following years after the end of the intensive development phase, the surveyed enterprises grew in linear way.

Gabrusewicz [1995] showed the growth as the most important goal of the company and introduced stages of this development and its difference towards the economic growth category. First of all it must be stated that there are many findings supporting the statement that the growth of economy is related to the growth of companies. Levine and Zervos [1996] found that larger, more efficient stock markets influence positively the economic growth. Obstfeld [1992] pointed out that the integration of markets may improve the rate of economic growth. Pradhan [2018] examined the long-run relationship between development of stock market and economic growth in G-20 countries and found unidirectional and bidirectional causality between development of stock market and per capita economic growth.

Nogalski et al. [2010] take notice of the escalating phenomenon of enterprise's fusions and takeovers in world's economy and for some time also in Poland. They tried to answer the question about motivations of management to undertake consolidation steps, and whether it is the result of transitional trends, an activity dictated by the popularity of this phenomenon, or it is a necessary process in the globalization era. Morck, Shleifer and Vishny [1990] suggested for example that market development can influence the growth in a negative way through takeovers.

Growth is related to the potential of growth that enhances the investment process. The basic definition of growth potential is related to the perspective of increasing the value of an enterprise, that depends on potential profits. The phenomenon of entity growth not only refers to profits, but also is the result of changes in the area of assets, equity or sales. In their work Miller and Modigliani [1961] presented a concept of growth potential, that can be defined as the current value of all future investment projects that the company decides to implement. According to Garbarski [2011], the potential can be considered in two aspects: as resources owned by the enterprise, i.e. material, human, financial resources and in the form of the ability to gather and mobilize resources. Both of these approaches determine effectiveness in meeting customer needs, as well as the effectiveness of the company's competition on the market.

In the investment process at the stage of the investor's selection of a potential object to allocate its capital, the growth potential of a given company plays 
a significant role. By assessing the potential of the organization, the possibilities of increasing the value of the enterprise should be analysed. The company's strategy, its formulation and implementation cannot take place without taking into account the unit's growth potential as its key component. When investing in the capital market, investors are interested in the future earnings of the company. Pomykalski [2011] concludes, based on his research, that an enterprise should also actively reduce its financing costs, as its potential growth may significantly affect the profitability of the organization.

According to Skalik [2012], the development potential of an entity is a set of both tangible and intangible resources that would only be launched as a result of internal and external stimulation. Innovations, for instance, play a key role in the structure of intangible assets. Resources in this form should allow abandoning imitation strategies, and should allow to focus on growth by emphasizing innovativeness, and this is a reference to the concept of Positive Organizational Potential.

The most recent analysis of the literature related to the growth of companies covers the issue of determinants of growth of small business that are the individual, organizational and environmental factors [Sarwoko and Frisdiantara 2016]. This study was conducted based on Indian companies. From the other hand Awartani and Millis [2018] performed the research based on Jordanian companies and found that the top five factors influencing the growth of small and medium companies are formality, education level of owner, sector, technology applied and the age of firm. It seems that developing countries, due to their growth and growth potential, have become a subject of the research.

On the basis of the literature analysis it can be stated that company's growth theory is constantly being extended. Over the years more new growth approaches have been proposed - from classical theories related to economies of scale, the theories emphasizing the role of businessman and innovations, through growth theories associated with costs and concerning the resources approach. On its basis many enterprise's growth models have been proposed. During every phase of growth there are some factors identified influencing further development possibilities and threats appearing during unit's activity. The problem with measuring company's growth is the selection of appropriate, relevant measures and verifying actual growth of the organization operating on a capital market.

\section{DATA AND METHODS}

The research was conducted on a group of companies from the business services sector, one of the largest traded on NewConnect in terms of market value. Most companies operating within the business services for firms sector deal with 
consulting in various forms, with the most common basic activity being accounting, tax services and business consulting in the broad sense. This sector is characterized by the number of 28 companies, but not all, due to the short trading period, are selected for the research sample. 21 enterprises in the period 2014 -2017 were chosen for the analysis. The data was collected from the Notoria database. Basic statistics for the services for companies sector are presented in Table 1.

Table 1. Statistics for the services for companies sector

\begin{tabular}{|c|c|}
\hline \multicolumn{2}{|c|}{ Statistics for services for companies sector } \\
\hline No of companies & 28 \\
\hline Market value & $336,26 \mathrm{mln}$ PLN \\
\hline Share in turnover & $2,24 \%$ \\
\hline Book value of companies in a sector & $184,6 \mathrm{mln}$ PLN \\
\hline
\end{tabular}

Source: NewConnect exchange.

An overall growth measurement indicator was presented by Delmar [2006]:

$$
g=\frac{R_{t_{1}}-R_{t_{0}}}{R_{t_{0}}}
$$

where:

$g$ - growth rate,

$R_{t_{1}}$ - volume of any variable at the end of the period,

$R_{t_{0}}$ - volume of any variable at the beginning of the period.

The growth measures are calculated using the following formulas:

one-year growth:

two-year growth:

$$
B_{01}=\frac{B_{1}-B_{0}}{B_{0}}
$$

$$
B_{02}=\frac{B_{2}-B_{0}}{B_{0}}
$$


three-year growth:

$$
B_{03}=\frac{B_{3}-B_{0}}{B_{0}}
$$

where:

$B_{01}$ - growth factor within 1 year,

$B_{02}$ - growth factor within 2 years,

$B_{03}$ - growth factor in 3 years,

$B_{0}$ - factor value in the base period,

$B_{1}-$ factor value over period 1 ,

$B_{2}$ - factor value over period 2,

$B_{3}$ - factor value over period 3 ,

$A, E, S$ - symbols of growth indicators: assets, equity, sales.

When measuring earnings per share (EPS), the formula is different due to the possible negative EPS value, and according to the methodology of Danbolt, Hirst and Jones [2011] it should be calculated with total assets in denominator as follows:

$$
E P S_{x y}=\frac{E P S_{y}-E P S_{x}}{T A S_{x}}
$$

where:

$E P S_{x y}$ - increase in earnings per share between periods $x$ and $y$, $E P S_{y}$ - value of earnings per share in period $y$, $E P S_{x}$ - value of earnings per share in the period $x$, $T A S_{x}$ - the value of assets divided by the number of shares in period $x$.

Another factor determining the company's growth on the capital market is its growth potential. Investors, when analysing the company, are more likely to buy shares of those enterprises that have a higher probability of growth. This is due to the fact, that they expect an increase in the value of shares of these companies.

Growth potential can be measured using capital market indicators or more complex models. The first and most important measure of growth potential is the Tobin's Q ratio [Tobin 1969], which is expressed as the market value of assets divided by the costs of replacing them. This relationship is represented by the formula: 


$$
T Q=\frac{M V C}{A R C}
$$

where:

$T Q$ - Tobin Q indicator,

$M V C$ - market value of capital invested in the enterprise, $A R C$ - cost of replacing assets.

However, as noted by Danbolt, Hirst and Jones [2011], the indicator presented by Tobin should be modified due to the difficulty in estimating the cost of replacing assets, and presented by the formula:

$$
T Q=\frac{T A+M V E-B V E}{T A}
$$

where:

$T A-$ total assets,

$M V E$ - market value of equity,

$B V E$ - book value of equity.

The higher the level of indicator, the higher growth potential of the enterprise. The level of Tobin's Q depends on the market and book value of equity and the book value of total assets. Thus the modified Tobin's Q reveals the company's potential included in the market price of shares. Tobin assumed that investor deciding to continue or finish the investment should be guided by the value of this ratio (when it is greater than one, investor should buy shares of the company). In this case, the market is assessing the capital invested in the enterprise above its replacement costs, and therefore the subsequent investments may increase the market value of the company [Stańczyk and Kryński 2007].

Otto [2000] presented a measurement of growth potential using the concept of value added. He proposed two models - the first of them concerns the exceeding value for the enterprise:

$$
\% P_{g} E V F=\frac{(M V E+B V D)-(B V E+B V D)}{(M V E+B V D)} \cdot 100 \%
$$

and:

$$
P_{g} E V F=(M V E+B V D)-(B V E+B V D)
$$


Second ratio represents the exceeding value for shareholders:

$$
\% P_{g} E V E=\frac{M V E-B V E}{M V E}
$$

and:

$$
P_{g} E V E=M V E-B V E
$$

where:

$E V F$ - value exceeding for enterprise,

$E V E$ - value exceeding for shareholders,

$M V E$ - market value of equity,

$B V E$ - book value of equity,

$B V D$ - book value of debt.

The higher the value of both indicators, the higher the growth potential of a given enterprise.

The next part of the article presents results of research related to the growth of companies in the business services for firms sector and its relationship to various indicators, especially the growth potential.

\section{RESULTS}

Business growth should be linked to the growth potential as companies present their strategies to the public. This situation occurs when the potential measures are appropriately adapted to the development opportunities of the company. First, basic statistics related to growth potential are presented in Table 2.

Based on the results presented in Table 2, it can be stated that the average values of the growth potential factors are positive, so it can be concluded that the average growth potential in the sector is positive, but it is not high.

Tables 3, 4 and 5 contain the results of an analysis of Spearman's rank correlation between measures of growth potential and measures of enterprise growth in the short (1 year), medium (2-year) and long term (3-year). In this step it is assumed that the relationship between the growth and growth potential measures is not linear. 
Table 2. Results of the basic statistical analysis of growth potential measures and measures of innovation among companies in the business services sector listed on the NewConnect market in 2014-2017

\begin{tabular}{|c|c|c|c|}
\hline Statistics & TQ & EVE & EVF \\
\hline Average & 2,166 & 0,1093 & 0,1786 \\
\hline Median & 1,455 & 0,4618 & 0,3225 \\
\hline St. deviation & 2,073 & 1,056 & 0,6431 \\
\hline Observations & 84 & 84 & 84 \\
\hline
\end{tabular}

Source: own study.

Table 3. Results of the analysis of Spearman rank correlation between measures of growth potential and measures of one-year growth companies listed in the sector of business services for firms on the NewConnect market for $t_{0}=2014$ based on data 2014-2017

\begin{tabular}{|c|c|c|c|c|c|}
\hline Variable & Stat. & A01 & E01 & S01 & EPS01 \\
\hline \multirow{4}{*}{ TQ } & Correlation & $\mathbf{- 0 , 5 0}$ & $\mathbf{- 0 , 4 9}$ & $-0,29$ & $-0,25$ \\
\cline { 2 - 6 } & z-score test & $-2,24$ & $-2,19$ & $-1,30$ & $-1,12$ \\
\cline { 2 - 6 } & p-value & 0,03 & 0,03 & 0,20 & 0,26 \\
\hline \multirow{4}{*}{ EVE } & Correlation & $\mathbf{- 0 , 4 1}$ & $\mathbf{- 0 , 5 0}$ & $-0,17$ & $-0,31$ \\
\cline { 2 - 6 } & z-score test & $-1,85$ & $-2,24$ & $-0,75$ & $-1,37$ \\
\cline { 2 - 6 } & p-value & 0,06 & 0,03 & 0,45 & 0,17 \\
\hline \multirow{4}{*}{ EVF } & Correlation & $\mathbf{- 0 , 4 9}$ & $-\mathbf{0 , 4 8}$ & $-0,29$ & $-0,24$ \\
\cline { 2 - 6 } & z-score test & $-2,17$ & $-2,13$ & $-1,30$ & $-1,08$ \\
\cline { 2 - 6 } & p-value & 0,03 & 0,03 & 0,19 & 0,28 \\
\cline { 2 - 6 } & No of observations & 21 & 21 & 21 & 21 \\
\hline
\end{tabular}

Source: own study.

Based on the results presented in Table 3, correlation is found in the short term between all growth potential measures TQ, EVE and EVF and the growth of assets and equity. The relationship between the growth potential and the increase in assets and equity is negative and it can be concluded, that the increase related to the investment projects is related with a simultaneous decrease in growth potential. Investments do not support the growth of the service company. However, all measures of growth opportunity do not show a statistically significant correlation with the increase in earnings per share. The same correlation analysis for the 2-year periods of growth of assets, equity, sales and earnings per share are presented in Table 4. 
Table 4. Results of the analysis of Spearman rank correlation between measures of growth potential and measures of two-year growth companies listed in the sector of business services for firms on the NewConnect market for $t_{0}=2014$ based on data 2014-2017

\begin{tabular}{|c|c|c|c|c|c|}
\hline Variable & Stat. & A02 & E02 & S02 & EPS02 \\
\hline \multirow{4}{*}{ TQ } & Correlation & $-0,25$ & $-0,25$ & $-0,19$ & 0,23 \\
\cline { 2 - 6 } & z-score test & $-1,14$ & $-1,11$ & $-0,87$ & 1,02 \\
\cline { 2 - 6 } & p-value & 0,26 & 0,27 & 0,39 & 0,31 \\
\hline \multirow{4}{*}{ EVE } & Correlation & $-0,19$ & $-0,28$ & $-0,10$ & 0,20 \\
\cline { 2 - 6 } & z-score test & $-0,85$ & $-1,26$ & $-0,43$ & 0,91 \\
\cline { 2 - 6 } & p-value & 0,40 & 0,21 & 0,67 & 0,36 \\
\hline \multirow{4}{*}{ EVF } & Correlation & $-0,24$ & $-0,24$ & $-0,20$ & 0,22 \\
\cline { 2 - 6 } & z-score test & $-1,09$ & $-1,06$ & $-0,88$ & 0,98 \\
\cline { 2 - 6 } & p-value & 0,28 & 0,29 & 0,38 & 0,33 \\
\cline { 2 - 6 } & No of observations & 21 & 21 & 21 & 21 \\
\hline
\end{tabular}

Source: own study.

Table 5. Results of the analysis of Spearman rank correlation between measures of growth potential and measures of three-year growth companies listed in the sector of business services for firms on the NewConnect market for $\mathrm{t}_{0}=2014$ based on data 2014-2017

\begin{tabular}{|c|c|c|c|c|c|}
\hline Variable & Stat. & A03 & E03 & S03 & EPS03 \\
\hline \multirow{4}{*}{ TQ } & Correlation & $-0,21$ & $-0,21$ & 0,35 & 0,14 \\
\cline { 2 - 6 } & z-score test & $-0,96$ & $-0,92$ & $-1,56$ & 0,61 \\
\cline { 2 - 6 } & p-value & 0,34 & 0,36 & 0,12 & 0,54 \\
\hline \multirow{4}{*}{ EVE } & Correlation & $-0,16$ & $-0,25$ & $-0,35$ & 0,10 \\
\cline { 2 - 6 } & z-score test & $-0,71$ & $-1,10$ & $-1,59$ & 0,46 \\
\cline { 2 - 6 } & p-value & 0,48 & 0,27 & 0,11 & 0,64 \\
\hline \multirow{4}{*}{ EVF } & Correlation & $-0,22$ & $-0,20$ & $-0,35$ & 0,13 \\
\cline { 2 - 6 } & z-score test & $-0,97$ & $-0,90$ & $-1,59$ & 0,56 \\
\cline { 2 - 6 } & p-value & 0,33 & 0,37 & 0,11 & 0,57 \\
\cline { 2 - 6 } & $\begin{array}{c}\text { No of } \\
\text { observations }\end{array}$ & 21 & 21 & 21 & 21 \\
\hline
\end{tabular}

Source: own study.

As a result of correlation analysis between the growth potential and growth in 2-year period it can be concluded, that non of them is statistically significant. The same analysis is presented in Table 5 for the long term growth of companies. 
The correlation between all measures of growth potential and growth measures in long period is not statistically significant.

The next part of the research is related to estimating the parameters of the linear regression model explaining the impact of selected factors on the growth of earnings per share in the short (EPS01), medium (EPS02) and long (EPS03) periods according to the methodology of Danbolt, Hirst and Jonson [2011]. Different versions of estimated parameters will be presented depending on the chosen measure of growth potential (TQ, EVE, EVF). Therefore, the variants of this model are as follows:

- model with Tobin Q:

$$
E P S_{G}=a+b_{1} T Q_{0}+b_{2} R O E_{-1}+b_{3} \Delta E P S_{0}+b_{4} \Delta T A_{0}+b_{5} \ln M V_{0}+e_{i}
$$

- EVE model:

$$
\begin{aligned}
& E P S_{G}=a+b_{1} E V E_{0}+b_{2} R O E_{-1}+b_{3} \Delta E P S_{0}+b_{4} \Delta T A_{0}+b_{5} \ln M V_{0}+e_{i} \\
& \text { - model with EVF: }
\end{aligned}
$$

$$
E P S_{G}=a+b_{1} E V F_{0}+b_{2} R O E_{-1}+b_{3} \Delta E P S_{0}+b_{4} \Delta T A_{0}+b_{5} \ln M V_{0}+e_{i}
$$

The parameters of the estimated regression model for the one year earnings per share growth EPS01 are presented in Table 6, for two years earnings per share growth EPS02 in Table 7, and for three years earnings per share growth EPS03 in Table 8.

Based on the data presented in Table 6, it can be noticed that in the short term, regardless of the selection of the growth potential measure, none of the variables explains the growth in earnings per share significantly. Thus, analysing the one-year EPS growth, it can be stated that there is no effect of exogenous variables on this increase.

Secondly, estimates of parameters are made for the EPS02 variable, and the results of the analysis are presented in Table 7.

The results presented in Table 7 indicate a negative and significant influence of ROE, EPS and total assets change on the growth of EPS in the period of 2 years.

The last estimates are made for the growth of EPS over a long, three-year period, and the results of the estimation of model parameters and statistics are presented in Table 8. 
Table 6. Results of estimation of model parameters with the EPS01 explained variable for enterprises of the business service for firms sector listed on the NewConnect market in 2014-2017, no of observations 21 .

\begin{tabular}{|c|c|c|c|c|c|c|c|c|}
\hline $\begin{array}{c}\text { Growth } \\
\text { potential } \\
\text { measure }\end{array}$ & & $a$ & $G P_{0}$ & $R O E_{-1}$ & $\Delta E P S_{0}$ & $\Delta T A_{0}$ & $\ln M V_{0}$ & \multirow{2}{*}{$S . R^{2}$} \\
\hline \multirow{2}{*}{ TQ } & Coefficient & $-4,41$ & $-0,12$ & 0,07 & $-0,06$ & $-0,01$ & 0,29 & \multirow{2}{*}{0,05} \\
\cline { 2 - 10 } & p-value & 0,14 & 0,42 & 0,65 & 0,27 & 0,96 & 0,14 & \\
\hline \multirow{2}{*}{ EVE } & Coefficient & $-3,65$ & $-0,27$ & 0,14 & $-0,07$ & 0,01 & 0,24 & \multirow{2}{*}{0,04} \\
\cline { 2 - 10 } & p-value & 0,19 & 0,49 & 0,16 & 0,20 & 0,92 & 0,19 & \\
\hline \multirow{2}{*}{ EVF } & Coefficient & $-3,78$ & $-0,43$ & 0,12 & 0,13 & 0,02 & 0,25 & \multirow{2}{*}{0,07} \\
\cline { 2 - 9 } & p-value & 0,17 & 0,36 & 0,99 & 0,22 & 0,88 & 0,17 & \\
\hline
\end{tabular}

Source: own study.

Table 7. Results of model parameter estimates with the EPS02 explained variable for enterprises in the business services for firms sector listed on the NewConnect market in 2014-2017, no of observations 21

\begin{tabular}{|c|c|c|c|c|c|c|c|c|}
\hline $\begin{array}{l}\text { Growth } \\
\text { potential } \\
\text { measure }\end{array}$ & & $a$ & $G P_{0}$ & $R O E_{-1}$ & $\triangle E P S_{0}$ & $\Delta T A_{0}$ & $\ln M V_{0}$ & $S . R^{2}$ \\
\hline \multirow{2}{*}{ TQ } & Coefficient & $-1,61$ & 0,09 & $-0,74$ & $-0,07$ & $-0,38$ & 0,10 & \multirow{2}{*}{0,93} \\
\hline & p-value & 0,33 & 0,27 & 0,00 & 0,05 & 0,00 & 0,38 & \\
\hline \multirow{2}{*}{ EVE } & Coefficient & $-2,20$ & 0,25 & $-0,79$ & $-0,06$ & $-0,40$ & 0,14 & \multirow{2}{*}{0,93} \\
\hline & p-value & 0,17 & 0,28 & 0,00 & 0,06 & 0,00 & 0,17 & \\
\hline \multirow{2}{*}{ EVF } & Coefficient & $-2,20$ & 0,16 & $-0,80$ & $-0,06$ & $-0,39$ & 0,14 & \multirow{2}{*}{0,94} \\
\hline & p-value & 0,18 & 0,57 & 0,00 & 0,08 & 0,00 & 0,18 & \\
\hline
\end{tabular}

Source: own study.

Analysing the results presented in Table 8 it can be stated that the growth potential measures influence positively the growth of EPS the same as ROE from the previous period. These results follow the theory of growth of companies. The negative impact of assets growth indicates that no investment is necessary for the growth of earnings in the business service sector for firms in long term. Unfortunately the EPS growth is related to the negative growth of market value indicating, that investors on NewConnect are impatient and they expect the results of their investments in a short term. 
Table 8. Results of the estimation of the parameters of the growth model with the explained variable EPS03 for enterprises in the business services for firms sector listed on the NewConnect market in 2014-2017, no of observations 21

\begin{tabular}{|c|c|c|c|c|c|c|c|c|}
\hline $\begin{array}{c}\text { Growth } \\
\text { potential } \\
\text { measure }\end{array}$ & & $a$ & $G P_{0}$ & $R O E_{-1}$ & $\Delta E P S_{0}$ & $\Delta T A_{0}$ & $\ln M V_{0}$ & \multirow{2}{*}{$S . R^{2}$} \\
\hline \multirow{2}{*}{ TQ } & Coefficient & $\mathbf{2 , 4 3}$ & $\mathbf{0 , 0 9}$ & $\mathbf{0 , 4 7}$ & $-0,01$ & $\mathbf{- 0 , 2 2}$ & $\mathbf{- 0 , 1 6}$ & \multirow{2}{*}{0,93} \\
\cline { 2 - 10 } & p-value & 0,02 & 0,07 & 0,00 & 0,56 & 0,00 & 0,02 & \\
\hline \multirow{2}{*}{ EVE } & Coefficient & $\mathbf{1 , 8 9}$ & $\mathbf{0 , 2 4}$ & $\mathbf{0 , 4 2}$ & $-0,01$ & $\mathbf{- 0 , 2 4}$ & $\mathbf{- 0 , 1 2}$ & \multirow{2}{*}{0,93} \\
\cline { 2 - 10 } & p-value & 0,04 & 0,06 & 0,00 & 0,74 & 0,00 & 0,04 & \\
\hline \multirow{2}{*}{ EVF } & Coefficient & $\mathbf{- 1 , 9 7}$ & $\mathbf{0 , 3 1}$ & $\mathbf{0 , 4 3}$ & $-0,01$ & $\mathbf{- 0 , 2 4}$ & $\mathbf{- 0 , 1 3}$ & \multirow{2}{*}{0,94} \\
\cline { 2 - 9 } & p-value & 0,03 & 0,05 & 0,00 & 0,64 & 0,00 & 0,03 & \\
\hline
\end{tabular}

Source: own study.

It can be concluded that in short term the growth of EPS may be not linear as the $\mathrm{SR}^{2}$ is very low for one year EPS growth. There is a significant and negative relationship between growth potential measures and growth of assets and equity found in the model. For 2-year EPS growth there is a negative influence of variables found with no growth potential measures being significant. Only 3 -year growth brings the rational results and both $\mathrm{ROE}$ and growth potential measures are significantly explaining the EPS growth.

\section{CONCLUSIONS}

The correlation analysis between growth potential and growth measures indicated a negative correlation in short term for all presented growth potential measures with assets and equity growth. Investors do not consider investment projects in the business services for firms sector as a value creators and assess it in a negative way in short term perspective.

The analysis of Danbolt, Hirst and Jones model showed, that in short term there was no influence of earnings per share growth by any explanatory variable, in the middle term - a negative influence of return on equity from the previous period, EPS change and total assets change on earnings per share growth when any growth potential measure was taken into consideration, in the long term - a positive influence of growth opportunity measures and return on equity from the previous period and a negative influence of change of assets and the market value were found. It can be assumed, that in longer term a positive influence of growth potential measures on earnings per share growth is visible and translates into companies' growth of value. 
The growth is analyzed with the nonlinear and linear models in this paper. In short term of growth analysis the nonlinear approach is statistically significant and in long term - the linear one. Basing on the results it can be concluded, that the theoretical observation related to the growth pattern of companies was confirmed. As the result of the research it is found that growth potential is negatively correlated with assets and equity growth in short term, but it affects positively earnings per share growth in 3-year period. It can therefore be concluded that in the sector taken into consideration investors' decisions reflected in the growth potential measures may be translated into company's value growth only in longer term.

The analyzed sector of business services for firms is specific due to the activity profile connected with the service and consultancy for other enterprises. A similar business profile is characteristic for large consulting companies known as Big Four, which greatly expanded since the beginning of their set-up and early stage of development. The analyzed enterprises started their activity on NewConnect, the alternative market, which involves the necessity of implementing some rules such as the transparency of financial documents and the investors' expectations. The growth potential properly reflects a possible value growth of examined units only in a longer term.

The average intangible to fixed assets ratio level in the sample taken into consideration value of approx. $31 \%$. Business service for firms companies operate within the innovative solutions, therefore the next research should focus on the role of innovations in the growth and growth potential of companies from different sectors, including the business services for firms companies.

\section{BIBLIOGRAPHY}

Ardishvili A., Cardozo S., Harmon S., Vadakath S., 1998, Towards a theory of new venture growth, In Babson entrepreneurship research conference, Ghent, Belgium, 21-23.

Awartani F., Millis B., 2018, Determinants of growth in micro and small enterprises: Empirical evidence from Jordan, In 2018 IEEE 5th International Conference on Data Science and Advanced Analytics (DSAA) 614-622. IEEE.

Bolek M., 2018, Determinanty wzrostu przedsiębiorstw na rynku kapitatowym, Wydawnictwo Uniwersytetu Łódzkiego, Łódź.

Christensen C.R., Scott B.R., 1964, Review of course activities, MEDE, Lausanne, 53.

Czarnecki M., 2011, Wzrost a rozwój przedsiębiorstwa, [w:] Sz. Cyfert (red.), Wybrane aspekty pracy kierowniczej, Wydawnictwo Uniwersytetu Ekonomicznego w Poznaniu, Poznań.

Danbolt J., Hirst I., Jones E., 2011, The growth companies puzzle: can growth opportunities measures predict firm growth?, „The European Journal of Finance”, vol. 17(1).

Davidsson P., 1991, Continued Entrepreneurship: Ability, Need, and Opportunity as Determinants of Small Firm Growth, „Journal of Business Venturing”, vol. 6, pp. 405-429.

Davidsson P., 1998, Determinants of entrepreneurial intentions, [w:] (Materiały) Konferencja RENT IX, November, Piacenza. 
Davidsson P., 1989, Entrepreneurship - and after? A study of growth willingness in small firms, „Journal of Business Venturing”, vol. 4, pp. 211-226.

Delmar F., 1994, The entrepreneur and the business effectiveness, [w:] (Materiały) Konferencja RENT VIII, Tampere, November.

Delmar F., Wiklund J., Davidson P., 2003, What Do They Think and Feel about Growth? An Expectancy-Value Approach to Small Business Managers' Attitudes Towards Growth, „Entrepreneurship Theory and Practice”, vol. 27(3), 247-270.

Delmar F., 2006, Measuring growth: Methodological considerations and empirical results, „Entrepreneurship and the Growth of Firms”, vol. 1, pp. 62-84.

Gabrusewicz W., 1995, Istota rozwoju przedsiębiorstwa, „Zeszyty Naukowe. Seria 1/Akademia Ekonomiczna w Poznaniu", nr (225), ss. 35-50.

Gajęcki R., 1997, Rozwój teorii przedsiębiorstwa. Podstawowe koncepcje, [w:] R. Gajęcki (red.), Rozwój firmy: teoria przedsiębiorstwa wprowadzenie, Szkoła Główna Handlowa, Warszawa.

Gancarczyk M., Gancarczyk J., 2011, Wzrost $i$ internacjonalizacja przedsiębiorstw $w$ klastrach, „Organizacja i Kierowanie. Organization and Management”, vol. 3(146).

Garbarski L., 2011, Marketing. Koncepcja skutecznych działań, PWE, Warszawa.

Greiner L.E., 1972, Evolution and revolution as organizations grow, „Harvard Business Review”, July-August, pp. 37-46.

Gruszecki T., 2002, Wspótczesne teorie przedsiębiorstwa, Wydawnictwo Naukowe PWN, Warszawa.

Hanks S.H., Watson C.J., Jansen E., Chandler G.N., 1993, Tightening the life-cycle construct: A taxonomic study of growth stage configurations in high-technology organizations, „Entrepreneurship Theory and Practice”, vol. 18, pp. 5-15.

Kallapur S., Trombley M.A., 1999, The Association between Investment Opportunity Set Proxies and Realized Growth, „Journal of Business Finance \& Accounting”, vol. 26(3\&4), pp. 505-519.

Kurczewska A., 2008, Problemy pomiaru wzrostu malych i średnich przedsiębiorstw, [w:] G. Maniak (red.), Problemy ekonomii i polityki gospodarczej, Materiały konferencyjne.

Levine R., Zervos S., 1999, Stock market development and long-run growth, The World Bank.

Lewis V.L., Churchill N.C., 1987, The five stages of small business growth, http://papers.ssrn.com/sol3/papers.cfm?abstract_id=1504517 [access 10.05.2016].

Lotti F., Santarelli E., Vivarelli M., 2003, Does Gibrat's Law hold among young, small firms?, „Journal of Evolutionary Economics”, vol. 13(3), pp. 213-235.

Machaczka J., 1998, Zarzadzanie rozwojem organizacji. Czynniki, modele, strategia, diagnoza, Wydawnictwo Naukowe PWN, Warszawa-Kraków.

McGuire J.W., 1963, Business and society, McGraw-Hill.

Miller M.H., Modigliani F., 1961, Dividend policy, growth, and the valuation of shares, „The Journal of Business”, vol. 34(4).

Morck R., Shleifer A., Vishny R.W., 1990, Do managerial objectives drive bad acquisitions?, „The Journal of Finance”, vol. 45(1), pp. 31-48.

Nogalski B., Kreft Z., Kapuściński M., 2000, Fuzje i przejęcia jako metody zewnętrznego wzrostu przedsiębiorstw, ,Prace Naukowe Akademii Ekonomicznej we Wrocławiu”, nr (851), ss. 71-81.

Obłój K., 2002, Tworzywo skutecznych strategii, PWE, Warszawa.

Obstfeld M., 1992, Risk-taking, global diversification, and growth (No. w 4093), „National Bureau of Economic Research".

Otto R.E., 2000, Valuation of Corporate Growth Opportunities - A Real Options Approach, Garland Publishing Inc., Taylor \& Francis, New York \& London.

Piasecki B., 1997, Przedsiębiorczość i mała firma, Wydawnictwo Uniwersytetu Łódzkiego, Łódź.

Piasecki B., 1998, Ekonomika i zarządzanie małą firmą, PWN, Warszawa-Lódź.

Pierścionek Z., 1997, Strategie rozwoju firmy, Wydawnictwo Naukowe PWN, Warszawa, 
Pomykalska B., 2010, Zarzadzanie procesem wzrostu przedsiębiorstwa: perspektywa finansowa, „Zeszyty Naukowe. Rozprawy Naukowe/Politechnika Łódzka”, z. 394, ss. 3-337.

Pomykalski P., 2011, Potencjat wzrostu organizacji - uwarunkowania finansowe, „Acta Universitatis Nicolai Copernici. Ekonomia", nr 42.

Pradhan R.P., 2018, Development of stock market and economic growth: The G-20 evidence, „Eurasian Economic Review”, vol. 8(2), pp. 161-181.

Sarwoko E., Frisdiantara C., 2016, Growth determinants of small medium enterprises (SMEs), „Universal Journal of Management”, vol. 4(1), pp. 36-41.

Scott M., Bruce R., 1987, Five stages of growth in small business, „Long Range Planning”, vol. 20(3), ss. 45-52.

Skalik J., 2012, Aktywizacja potencjalu rozwojowego przedsiębiorstwa, [w:] A. Stabryła (red.), Determinanty potencjału rozwoju organizacji, Fundacja Uniwersytetu Ekonomicznego w Krakowie, Kraków.

Stańczyk J., Kryński Z., 2007, Metody pomiaru wartości kapitału intelektualnego przedsiębiorstwa, „Nierówności Społeczne a Wzrost Gospodarczy”, nr 10.

Steinmetz L.L., 1969, Critical stages of small business growth: When they occur and how to survive them, „Business horizons”, vol. 12(1), pp. 29-36.

Sysko-Romańczuk S., 2005, Rozwój przedsiębiorstwa jako rezultat jego wzrostu i sprawności procesów zarządzania, „Rozprawy i Studia/Uniwersytet Szczeciński”, z. 570.

Tobin J., 1969, A General Equilibrium Approach to Monetary Theory, „Journal of Money, Credit, and Banking", vol. 1(1), pp. 15-29.

Wasilczuk J., 2005, Wzrost małych i średnich przedsiębiorstw: aspekty teoretyczne i badania empiryczne, Wydawnictwo Politechniki Gdańskiej, Gdańsk.

Wiklund J., 1996, Theoretical perspectives in research on firm growth, [w:] (Materiały) Konferencja RENT X, Brussels, November. 